\title{
Article
}

\section{Women Scientists and the Freshwater Biological Association, 1929-1950}

Toogood, Mark D., Waterton, Claire F.J. and Heim, M. Wallace Available at https://clok.uclan.ac.uk/23540/

Toogood, Mark D. orcid iconORCID: 0000-0003-2403-0338, Waterton, Claire F.J. and Heim, M. Wallace (2020) Women Scientists and the Freshwater Biological Association, 1929-1950. Archives of Natural History, 47 (1). pp. 1628. ISSN 0260-9541

It is advisable to refer to the publisher's version if you intend to cite from the work. https://doi.org/10.3366/anh.2020.0618

For more information about UCLan's research in this area go to http://www.uclan.ac.uk/researchgroups/ and search for <name of research Group>.

For information about Research generally at UCLan please go to http://www.uclan.ac.uk/research/

All outputs in CLoK are protected by Intellectual Property Rights law, including Copyright law. Copyright, IPR and Moral Rights for the works on this site are retained by the individual authors and/or other copyright owners. Terms and conditions for use of this material are defined in the policies page.

\section{CLoK}

Central Lancashire online Knowledge www.clok.uclan.ac.uk

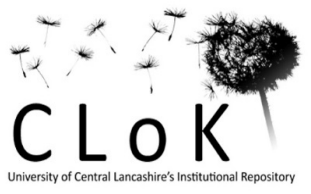




\title{
Women Scientists and the Freshwater Biological Association, 1929-1950
}

\author{
MARK TOOGOOD ${ }^{\mathrm{A}}{ }^{\text {CLAIRE WATERTON }}{ }^{\mathrm{B}}$ and WALLACE HEIM ${ }^{\mathrm{C}}$

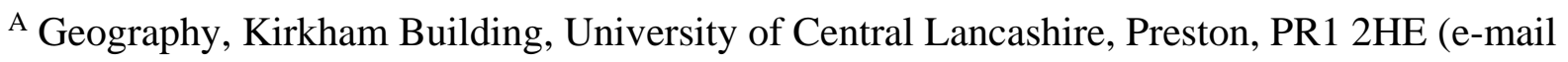 \\ mtoogood@uclan.ac.uk).
}

${ }^{\mathrm{B}}$ Centre for the Study of Environmental Change, Sociology Department, Lancaster University, LA1 4YT.

${ }^{\mathrm{C}}$ Low Wood, Haverth waite, Ulverston, Cumbria, LA12 8LY.

Accepted for publication: Archives of Natural History, Volume 47, No. 1, to be issued in April 2020 (by Edinburgh University Press).

\begin{abstract}
In the early to mid-twentieth century, women had limited opportunities to develop and practice as scientists and, when they did, were often marked out: regarded as remarkable because they were women with scientific commitment, in contrast to their male counterparts. Opportunities in freshwater science arose in England in a number of interconnected institutions centred on the Freshwater Biological Association (FBA) founded in 1929. Several women scientists pioneering in their fields were nurtured by the FBA, such as early freshwater researchers, Penelope Jenkin, Marie Rosenberg and Winifred Frost, the last two being the first professional women naturalists at the FBA. Other researchers who achieved distinction in their field were also products of the FBA and its imperial and university network, including, Rosemary Lowe, Winifred Pennington, Kate Ricardo, Carmel Humphries and Maud Godward, for example.
\end{abstract}

KEY WORDS: Freshwater Biological Association - women scientists - imperial science twentieth century - limnology - ichthyology

\section{INTRODUCTION}

In May 2014, the Royal Society hosted a conference on the theme of 'Women in Science, 1830-2000'. The conference sought to revisit women's participation in science, to open up historical research into the roles of women scientists and to reflect on how history can inform 
insight into the contemporary role of women in science (Jones and Hawkins 2015). As the conference emphasised, the prevalent historical image of women scientists was, and perhaps still is, a caricature. A woman scientist was regarded foremost as an atypical woman: a superwoman, or a harridan, for example; as forgoing her femininity; as something to be marvelled at. The conference also highlighted that the twentieth century was one in which the contribution of women in making science was largely invisible. The normal idea of scientific achievement being marked by the concept of the (male) individual 'breaking through' in a particular area of science was a construct which served to shut women out of the history of science. Women in the late nineteenth and early twentieth century were actively involved in making science, but typically as part of work in factories, museums, schools, military production and relatively small specialist organisations, rather than in places which society, as well as historians of science, have habitually associated with scientific accomplishment.

The conference came at a time when the authors of the present paper were beginning research in the archives of the Freshwater Biological Association (FBA), based at Far Sawrey on Lake Windermere in the English Lake District. Our research sought to explore in detail some of the anecdotes about the culture of the FBA in the early twentieth century. It was said that the FBA positively encouraged the training of women scientists, employing several of them in its core scientific staff. Facts showed there were a number of women undertaking pioneering scientific work right from the organisation's inception in 1929. This was in an age when women holding investigative scientific positions, particularly in grant-aided organisations such as the FBA, were highly unusual. Some of these women spent much of their career at the FBA and associated organisations in the British Empire, becoming innovators of new knowledge and techniques, furthering new understanding in freshwater sciences such as limnology, ichthyology and algology. Haworth (2007) suggests that these women became a new generation of respected researchers

In this paper, we focus on women scientists in the FBA at its first laboratory and in its wider international network in the British Empire during the inter-war and immediate post-war period. Our objective in doing so is to capture a sense of the growth of opportunities for women scientists as the freshwater sciences developed. There are other broad accounts of the history of freshwater science, but none that focus on women scientists (e.g. Talling 2008). Our approach to women in the FBA treats natural history and science as alive with historical, social, cultural and philosophical importance, alongside its scientific significance - and 
requiring interpretation as such (Fox 1999; Daston 2008; Landecker 2016). In other words, science is a social phenomenon. This approach does not regard 'gender' as a determining category, as the scientific culture of the twentieth century predominantly did, but as something that is the product of what is done within and organised through the institutions, assumptions and conventions of science (Schiebinger 1989; West and Zimmerman 1987; Benschop and Brouns 2003; Watts 2007). Therefore, gender is considered as something that is part of science, as it is of society more widely. The history of the FBA is explored as a place in which women were remarkable pioneering scientists amongst other pioneering scientists, rather than being remarkable for being women.

\section{WOMEN AND SCIENCE IN ENGLAND - AN HISTORICAL OVERVIEW}

There was at the time a pervasive idea that women were unsuited to intellectual pursuits and were far more suited to domestic spaces and work than to scientific work (Marsden and Omery 1992; Von Oertzen et al 2013). Women at Birkbeck College in London were first permitted to attend scientific lectures in 1832. A movement to enable women to gain full entrance to higher education achieved its first success in 1869 when women could take the Cambridge University entrance examinations, leading to the foundation of women only institutions: Girton College in 1869 and Newnham College in 1871 (Richmond 1997). Although women could study science subjects and even take examinations in the Cambridge Natural Science Tripos, they could not be awarded a degree or become members of Cambridge or Oxford Universities until 1948 and 1920, respectively. In 1922 a Royal Commission upheld Cambridge's rejection of women as degree students (Dyhouse 1995). In science lectures at Cambridge the physical segregation of women was an unwritten rule and women would often be confined to a gallery or to certain rows of seating. They were not permitted to interact with lecturers (Richmond 1997).

In 1925, the Cambridge zoology undergraduate, Sidnie Manton, (elected FRS in 1948 on the basis of her research on arthropods), was denied the University Prize she would have won for coming top of the Part II Zoology in the Natural Science Tripos because women could not be members of the university (Fryer 1980). Other universities did allow women to achieve degrees. London University, for example, first admitted women in 1878, and between 1900 and 1938 , the proportion of women students rose steadily to about 25 per cent of the total (Dyhouse 1995, 17). Dr Nellie Eales was among the first women to graduate with a zoology 
degree in 1907. She later worked at the Marine Biological Association in Plymouth and taught some women scientists associated with the FBA, such as Ethelwynn Trewavas. ${ }^{1}$ There were other notable attainments by women. For example, in 1904 The Linnean Society of London permitted women to become Fellows, 15 being elected that year, including, the naturalist-photographer, Emma Turner; palaeophytologist, Margaret Benson; and Annie Smith, a keeper of cryptogrammic plants at the British Museum (Natural History).

There were examples that represent early educational opportunities for women in science, that run counter to the struggle for acceptance portrayed above. In 1903, Swanley Horticultural College in Kent (later to become part of Wye College, University of London), began an experiment to make its curriculum more scientific (a strategic move, partly to aid solutions to the agricultural depression at the time). As women students were achieving more highly in its science subjects, and its male students were largely receiving training for horticultural apprenticeships, it decided to adopt a policy to admit only female candidates (Optiz 2013). Another example is the Balfour Biological Laboratory for Women, established at Cambridge University between 1884-1914 (the year women were finally admitted to study in university laboratories). The Balfour Laboratory instructed women in the full range of biology so that they could effectively take tripos examinations. The Balfour Lab was especially significant after women were shut out of practical classes in 1886 (Richmond 1997, 447). It became a locus for women scientists otherwise marginalised and often directly excluded from mainstream science and the scientific support system enjoyed by men. In effect the Balfour Laboratory gave rise to a feminized scientific subculture, including women's scientific societies and women-sponsored college fellowships (Richmond 1997, 455).

Although women students were encouraged to maintain their studies during the First World War, the rush of women into war work was not reflected in increased permanent opportunity in the sciences. As Fara puts it, "[w]hile male university students were dying at the Front, their female counterparts were treated like children" in being assigned menial and repetitive tasks that underemployed their abilities $(2015,16)$. Despite the widespread image of women being set free from domesticity by the First World War only a very few experienced the scientific liberty afforded to men, and the status quo was quickly re-established after the Armistice (Fara 2018). 
Given that at least twenty women were working or training at the FBA in its early years (from 1929 onwards), ${ }^{2}$ it is right to ask whether a distinctive social and institutional culture may have developed there that, at least in some respects, disregarded gender distinction. The first degree programme in freshwater biology in Britain was started at Cambridge by $\mathrm{J} \mathrm{T}$ Saunders, with Barton Worthington (first director of the FBA) and Penelope Jenkin, (an early FBA researcher), being part of the initial cohort of graduates in 1925 - although Jenkin would have received a certificate rather than a degree. Jenkin was perhaps the first student to finish Saunders' course on hydrobiology (Slack 2010, 143).

However, overt discrimination against women, such as bars to membership of scientific organisations, and requirements for women to resign on marriage, limited their career options. The latter discrimination applied to civil service and academic science. In 1928, for example, the academic Dr Kathleen Drew (later the founder and the first President of the British Phycological Society), was obliged to leave her lectureship at Manchester University when she married, whilst her husband was able to retain his academic post (Brodie 2010). Therefore, we can ask whether the FBA, or perhaps networks of freshwater science more broadly, opened up institutional norms, broadening women's opportunities to take on scientific roles (Madsen-Brooks 2009).

\section{WOMEN AND THE FRESHWATER BIOLOGICAL ASSOCIATION}

The Freshwater Biological Association of the British Empire, was established in $1929 .{ }^{3}$ It was funded by the Development Commission, private subscriptions, some university assistance, and the support of bodies from the water industry. Its stated aim was to 'prosecute research into the fundamental problems of freshwater biology' through the establishment of a British research station with accommodation and a laboratory (Anonymous 1933; Fritsch 1937), although the Development Commission later favoured applied research. The FBA was first headquartered at Wray Castle, a crenelated, gothic revival property, built in 1840 on the north-western shore of Lake Windermere. ${ }^{4}$ In 1929 the National Trust took possession of Wray Castle and immediately leased it to the FBA, thus establishing a research station based on one set up by the Hungarian government on Lake Balaton (Anonymous 1930). The staff of the new organisation started to alter the space to accommodate several laboratories as well as residential space for researchers and visitors. 
One of the early customs that contributed to a distinctive research culture at the FBA was that of the annual Easter Class for students. The Annual Report of the FBA Council published in the summer of 1933 gives a feel for how these classes began and how they fed into the research at FBA:

The Council considered that such a class would bring to the notice of the Universities the facilities of the Laboratory and would also encourage young students to undertake research in freshwater problems. Dr Pearsall, Mr Saunders and the staff expressed their willingness to conduct a class during a fortnight of the Easter Vacation. Notices of the class were sent to all the Universities and University Colleges in Great Britain and Ireland and an embarrassing number of applications to attend was received. The original proposal was to have a class of six students, but the number of applications made it desirable to increase this number and thirteen students were, with difficulty, accommodated. Thirteen applications had to be refused. Seven Universities were represented in the class, and, in spite of the crowded conditions and rather unfavourable weather, it proved a great success.

(Anonymous 1933, 12)

These classes attracted many male and female students and there seems to have been a distinct lack of scientific hierarchy. The classes were not a matter of a senior member of FBA staff dispensing knowledge. Rather, they involved all participants in doing science. Students might, for example, initiate and carry out a detailed survey of a stream, looking at the chemical, biological and physical characteristics and creating scientific evidence and analysis. In fact, two of these students, Miss QE Hobbs and Miss EM Oliver, worked on soluble nitrogen and species presence in streams in 1932 (Anonymous 1933). The following year, 30 percent of the FBA research projects being carried out were being undertaken exclusively by female scientists. Miss CM Humphries of University College Dublin, for example, conducted a research project on chironomid larvae, and Miss M Vincent of Cambridge University conducted research on mosquito larvae. Miss MB Godward of East London College studied shore algae, Miss FM Willis studied photosynthesis under changing light conditions, whilst Miss QE Hobbs continued her stream work from the previous year and showed that the chemical composition of water in streams varied within a short distance. (Anonymous 1933, 8).

At least two of the above students went on to become prominent in their field. Maud Godward received a fellowship through Fritsch for postgraduate work at the FBA. After that, and via a series of short-term academic contracts, she secured a botany lectureship at Queen Mary's College, University of London. As a former student of Fritsch she could, apparently, 
be relied upon to deliver the specific subject matter to the high level that Fritsch considered a requirement of a biology degree. Ultimately, Godward became Professor of Phycology at Queen Mary College (QMC), also serving as Vice-President of the British Phycology Society. Godward Square on the QMC Mile End site in London is named after her.

A second example of a successful academic career is Carmel Humphries. She received a grant for residential study at Wray for the year 1934-5 conducting research on benthic fauna (with Winifred Frost - an ichthyologist), and publishing her work in the Journal of Animal Ecology (Humphries 1936). After joining University College Dublin as a lecturer in 1939, she continued her work on Chironomidae initiated at the FBA. In 1957 Humphries was appointed head of school and professor of zoology at UCD. The chironomid, Zalutschia humphriesiae is named after her.

Most of these of these researchers were students who went on to undertake funded research at the FBA. Many of those came from universities with Cambridge University and London University the most prominent. The reason for these universities sending many students was that academics held council positions within the FBA. The link to Cambridge was John Saunders who was a senior member of the Botany Department's academic staff. Felix Fritsch, was professor of Botany at the East London College (which became QMC in 1934). Both Saunders and Fritsch were key members of the British Association committee that in 1928 helped drive the argument for the need for a freshwater biological station in Britain (Fritsch 1937, 33). The other key figure central to the influx of students in the FBA's early years was William Pearsall. Pearsall was a Reader in Botany at the University of Leeds. Between 1931 and 1937, he was Honorary Laboratory Director of the FBA, and became President of the British Ecological Society in 1936 (Anonymous 1938). Pearsall vacated the honorary post only on his appointment as Professor of Botany at Sheffield University in 1937.

Both of the first professional naturalists at Wray Castle were research students supervised by Saunders at Cambridge. They were Philip 'Pip' Ullyott (Naturalist-in-Charge) and Bobby Beauchamp (Assistant Naturalist). In 1932, before taking up their appointments, they were absent travelling in Finland. Whilst there, Penelope Jenkin arrived to work on the chemical composition of lake water in different seasons and also on the zooplankton of Lake Windermere (Lund 1984). The fact that the first naturalist to conduct any systematic work at the FBA was a female might not have been a simple coincidence. Jenkin was the more 
experienced Saunders protégé, and had demonstrated her abilities, not least as a member of the 1929 expedition to study the soda lakes of Kenya (Jenkin 1936).

Another important female scientist during the FBA's early years was Marie Rosenberg. She arrived at Wray Castle from Birkbeck College in 1934 to conduct research into the filamentous growth of algae, becoming a resident researcher from April 1935 (Anonymous 1936). In January 1938, she was appointed as the Naturalist in Algology at the FBA, the first female to obtain a permanent naturalist position. However, Rosenberg's status as a refugee (she had originally left Vienna to escape Nazi persecution), led to her removal from active research despite the efforts of her FBA colleagues to prevent it. In summer 1939, she was informed by the authorities that she would in due course receive naturalization papers. However, on 10 May 1940, the day the German army attacked France, the Netherlands and Belgium, a police car arrived at Wray to take Rosie and two Austrian staff working at Barton Worthington's house away and into internment. ${ }^{5}$ On her release, after a year's confinement, partly due to FBA staff objections to her incarceration, she was treated as a foreign alien, officially forbidden from residing in a coastal county (Wray Castle was then in Lancashire), and her research was effectively halted. She later moved to Cambridge to work at Saunders' laboratory.

The ichthyologist, Winifred Frost was appointed as the second full-time female Naturalist at the FBA, joining in February 1939 (Anonymous 1939). Frost is known for her work on eels (Anguilla anguilla). During World War II, Winifred Frost and her full-time assistant, Rosemary Lowe, were asked by the War Office to look at the commercial trapping of eels as a food source (Frost 1945, 1946; Bagenal 1970). Their work extended well beyond this applied focus to include a sensitive and thorough understanding of the natural history and biology of the eel. Their research was also experimental, using home-made novel experimental apparatus - such as the tank for testing elvers' responses to light. The tank they used-known as 'the River Styx' was situated in the basement of Wray Castle. ${ }^{6}$ During the war WEF, as Frost was known, became the only permanent member of scientific staff left at Wray Castle due to other male scientists enlisting for active duty. Winifred Frost went on to work on a number of fish species, notably becoming a globally recognised expert on game species in collaboration with Charlotte Kipling from Newnham College. ${ }^{7}$ The culmination of 
this focus was The Trout, a book that took 20 years of research and writing with Margaret Brown (Frost and Brown 1967).

In 1936, Winifred Pennington, from Barrow in Furness, not far from Windermere, approached Mr Beauchamp, then the Naturalist-in-Charge, about using her vacation from Reading University to work on a series of projects at Wray Castle. She received a very warm welcome (Lund 1984). She became a prolific researcher - similar to other women resident at the Laboratory and fitted in accordingly. Her research included work on the anatomy of Fucus (Pennington 1937), stream mosses (Pennington 1949), and the red freshwater algae Hildenbrandia. She also discovered a new coccoid algae genus, Diogenes whilst conducting experimental investigation of the utilisation of nitrogen by lake algae (Pennington 1942). It was her attendance at the 1941 Easter class that lead to a transformation in her interest away from algology and, according to John Lund, formed "the seedbed for the flowering of British limnology" (Lund 1984, 2).

Pennington's initial work on lake sediments was mostly inspired by the botanist Harry Godwin at Cambridge and also by her colleagues Clifford Mortimer and, later, John Mackereth at the FBA. Another important colleague at the FBA was William Pearsall with who she wrote an 'amazingly perceptive' (Birks and Birks 2007, 603) paper on the natural history of the Lakes (Pearsall and Pennington 1947). After Pearsall's death, she used his plan and notes to write The Lake District (Pearsall and Pennington 1973). ${ }^{8}$ Her work supplies evidence of a general sequence of late and post-glacial vegetational changes, thereby pioneering the field of paleolimnology (Pennington 1943, 1947). In 1942, she married a fellow botanist she had met at Wray Castle, Thomas Tutin. She did relocate from Wray to Cambridge University Botany Department in 1944 but returned to serve on the FBA Council 1958-1967 and joined the FBA staff in 1967 as a Principal Scientific Officer to work on lake sediments, forming her own Quaternary Research Unit. ${ }^{9}$ The credibility and reach of this research had genuine resonance evidenced in part by the fact that some of the most eminent freshwater scientists of the time, such as Evelyn Hutchinson, made study visits (Slack 2010, 144). 
Two other Fritsch protégés were notable for a creative collaboration on microscopical algology from 1943 onwards. Hilda Canter became an important pioneer of photomicrography of algae working at the FBA, first as a PhD student, then as mycologist from 1948. She, John Lund (then holding the FBA position of Algologist, also from QMC), and the assistant algologist, Brenda Knudson, built up a specialist algology team at the FBA after the war. One of these areas of research in this general area was microbiological: understanding the fundamental links between fundamental research in bacteriology and how these applied to freshwater management, particularly in the water industry. From 1947 Vera Collins was working in this area, again leading research and pioneering the application to practical issues (Collins 1964).

\section{IMPERIAL SCIENTIFIC OPPORTUNITIES FOR WOMEN}

The FBA was tied into a wider international network of colonial science and institutions which provided a context for women scientists to find opportunities. The complex and ambitious African Research Survey overseen by Lord Hailey, 1929-1938, was influential in pioneering new directions for freshwater science. This came about partly through the Survey placing science at the centre of solutions to African problems and its identification of future research needs to underpin solutions. Julian Huxley, one of the instigators of the African Survey, was very conscious of the need for new science to become involved in identifying and dealing with African 'problems' such as food supply. It was Huxley who secured Barton Worthington as the scientific director for the Survey (Worthington 1990). Worthington went on to become the first Director proper of the Freshwater Biological Association of the British Empire (between 1937 and 1946), and, after Parliament passed the Colonial Development and Welfare Act (1940), Worthington became the Secretary of the then new Colonial Research Committee (CRC) which drove forward regional scientific research in East Africa between 1946 and 1951. Worthington was foremost in arguing that fish from inshore freshwater sources in colonial Africa was an underdeveloped resource (Worthington 1943). Long-range research initiatives, including into fisheries in Africa were put in place through the establishment of the Colonial Development Fund in 1929. They were further enhanced after the 1938 African Survey and the 1940 Colonial Development and Welfare Act that directly led to the creation of the CRC and of a Colonial Development and Welfare Fund 
(CDWF) and, in 1943 a Colonial Fisheries Advisory Committee (Hodge 2007, 106; Worthington 1943, 355).

It is also relevant that scientists had found opportunities in colonial research before finding openings in Britain. Examples are Penelope Jenkin with the Percy Sladen expedition to Kenya in 1929 and Stella Worthington to Uganda and Kenya in 1927-28 and 1930-31 (Worthington and Worthington 1933). In 1939, a survey of Lake Nyasa involved Kate Ricardo (then doing research at the FBA) and Ethelwynn Trewavas (of the British Museum (Natural History)) (Bertram et al 1942). A follow up to this expedition focusing on research into the fishes of Nyasaland took place in 1945, the principal researcher being Rosemary Lowe who had worked on the eel project under Winifred Frost.

The East African Fisheries Research Organisation (EAFRO) at Jinja in Uganda on Lake Victoria, was originally conceived by Barton Worthington and Michael Graham in 1929 and was set up in 1947 as a regional centre, based on Worthington's model of a network of institutions sharing staff in England and Africa (Worthington 1983; Worthington 1943). This station has been described as the African arm of the FBA. In March 1948, Winfred Frost was seconded from the FBA at the behest of the Colonial Office to spend six months at Jinja to help establish a research programme for the EAFRO then coming into being (Anonymous 1948). The Director of this new organisation was Bobby Beauchamp, formerly the FBA's first Naturalist-in-Charge. Other women freshwater scientists working at EAFRO during its early days with connections to the FBA were Peggy Varley (1950-1951) and Mouse Osmaston. After a sojourn back at Wray Castle, in 1947 Rosemary Lowe successfully interviewed for a post with the then new Overseas Research Service (ORS). Her posting was to EAFRO where "her remit was to study the biology and fisheries potential of tilapias in the East African lakes, a task she undertook with remarkable skill and ecological acumen" (Stiassny and Kaufman 2015, 1719; Lowe-McConnell 1975; Lowe-McConnell 2006). Lowe's field study gave a thorough account of the tilapia fisheries in East Africa and formed the basis of subsequent studies of Malawian cichlids (Bruton 1994). Lowe's work also was considered to have "revolutionized global studies on freshwater ecosystems and fish production" (Reid 2016, 443).

Those women scientists in the ORS who married were expected to resign, an example being Rosemary Lowe-McConnell who had to resign from the Colonial Service on her marriage in 1953, despite the marriage bar having been lifted in the home Civil Service in 1946 (Bruton 
1994, 71). In 1997 after she received the Linnean Medal of Zoology for her life time of scientific achievement in ichthyology, Lowe-McConnell commented, "not bad for someone who hasn’t had a job since 1953!” (quoted in Stiassny and Kaufman 2015, 1722).

\section{CONCLUSION}

The FBA was established a year after electoral equality for women was achieved by the passage of the Representation of the People (Equal Franchise) Act 1928. This equality of franchise was not generally reflected in scientific institutions. As Des Jardins demonstrates, most women scientists were dissuaded from lab and field research and frequently were encouraged into 'suitable' occupations such as teaching, librarianship and editing - and especially "mundane tasks that would bore men with similar credentials" $(2010,127)$.

Some male scientists in the FBA were known to disparage women (such as Pip Ullyott). ${ }^{10}$ But it is notable that at the FBA all unmarried scientists lived and worked together as a community, and the same is true of the EAFRO in Uganda. It seems that the FBA was a pocket of difference in an environment in which men were appointed above women as a matter of course. Ethelwynn Trewavas suggests that women were treated more equally in the freshwater sciences because they, like their male colleagues, were all specialists, all had something relevant to contribute to both the advancement of freshwater sciences as a whole, and to the institutions they worked in (Noakes 1994, 63). Men did dominate the management and Board positions of the FBA, yet women scientists, such as Marie Rosenberg and Winifred Frost, were appointed to senior naturalist positions, a rare occurrence in scientific institutions for a longtime after the Second World War. Freshwater science was first and foremost a community of scientists, rather than a culture divided on gender which elevated male members to the rank of scientific heroes and female scientists to the caricature of extraordinary women. 


\section{ACKNOWLEDGEMENTS}

We would like to thank the Council and the staff of the FBA for their support and collegiality, particularly Dr Isabelle Charmantier (now at The Linnean Society), Dr Bill Brierley, Dr Anne Powell, Dr Elizabeth Howarth and Rosalind Maberly. We also express our gratitude to Gina Douglas for the invitation to present a paper to the SHNH annual conference, 2017.

\section{NOTES}

1. Trewavas was first appointed to the Freshwater Biological Association Council in 1943. Council papers 1943. Freshwater Biological Association Archives (hereafter FBA Archives).

2. From staff lists in FBA annual reports, 1929-1940.

3. As it was called for its first 20 years. The change of name came about in 1947-48. This was followed by the FBA relocating its headquarters from Wray Castle southwards down Lake Windermere to The Ferry House, Far Sawrey, in the autumn of 1950 (Fritsch 1951).

4. John Lund described Wray Castle as 'a Victorian monstrosity ill-designed for living in or, it seemed, working in' (Lund 1984, 1).

5. FBA Archives, Far Sawrey: Macan, Thomas T. [no date] Recollections of the Freshwater Biological Association, or What You Will Not Find in the Annual Report. Unpublished paper, p22.

6. FBA Archives, Far Sawrey: Lowe eels' files.

7. FBA Archives, Far Sawrey: Box 168.

8. Pearsall died in 1964.

9. $\quad$ FBA Archives, Far Sawrey: Tutin, Winifred. 2003. What I did, publications: 19372003. Unpublished paper.

10. FBA Archives, Far Sawrey: Macan, Thomas T. [no date] Recollections of the Freshwater Biological Association, or What You Will Not Find in the Annual Report. Unpublished paper.

\section{REFERENCES}

ANONYMOUS, 1930. Report of the Freshwater Biological Association of the British Empire conference held at Fishmongers' Hall on Friday, February 21 ${ }^{\text {st }}, 1930$. Ambleside. 
ANONYMOUS, 1933. Freshwater Biological Association of the British Empire, Report of Council, Subscription List and Accounts for 1932. Ambleside.

ANONYMOUS, 1936. Freshwater Biological Association of the British Empire, Fourth Report of Council, Subscription List and Accounts for the Year Ending 31 March 1936. Ambleside.

ANONYMOUS, 1939. Freshwater Biological Association of the British Empire, Seventh Report of Council, Subscription List and Accounts for the Year Ending 31 March 1939. Ambleside.

ANONYMOUS, 1948. Freshwater Biological Association of the British Empire, Sixteenth Annual Report of Council, Subscription List and Accounts for the Year Ending 31 March 1948. Ambleside.

BAGENAL, Timothy B., 1970. An historical review of the fish and fisheries investigations of the Freshwater Biological Association, mainly at the Windermere Laboratory. Journal of Fish Biology 2 (2): 83-101.

BENSCHOP, Yvonne, and Margo BROUNS, 2003. Crumbling ivory towers: academic organizing and its gender effects. Gender, Work and Organization, 10: 94-212.

BERTRAM, Kate, John BORLEY and Ethelwyn TREWAVAS, 1942. Report on the Fish and Fisheries of Lake Nyasa. London.

BIRKS, Harry, and Hilary BIRKS. 2007. Winifred Tutin (1915-2007). Journal of Paleolimnology 38: 601-605.

BRODIE, Juliet, 2010. Drew, Kathleen (1901-1957). Oxford Dictionary of National Biography. DOI: 10.1093/ref:odnb/94193 (accessed 21 September 2018).

BRUTON, Michael, 1994. The life and work of Rosemary Lowe-McConnell: pioneer of tropical fish ecology. Environmental Biology of Fishes 41, 67-80.

COLLINS, Vera. 1964. The fresh water environment and its significance in industry. Journal of Applied Bacteriology 27 (1): 143-150.

DASTON, Lorraine, 2008. On scientific observation. Isis 99: 97-110.

DES JARDINS, Julie, 2010. The Madame Curie Complex: The Hidden History of Women in Science. New York City.

DYHOUSE, Carol, 1995. No Distinction of Sex? Women in British Universities, 18701939. London.

FARA, Patricia, 2015. Women, science and suffrage in World War I. Notes and Records: The Royal Society Journal of the History of Science 69: 11-24.

FARA, Patricia, 2018. A Lab of One's Own: Science and Suffrage in the First World War. Oxford. 
FOX, Mary Frank, 1999. Gender, hierarchy, and science. Janet Chafetz, editor. Handbook of the Sociology of Gender, pp 441-457. New York City.

FRITSCH, Felix, 1937. The early history of the Association. Seventh Annual Report of Council, Subscription List and Accounts for the Year Ending 31 March 1937. pp 33-41.

FRITSCH, Felix, 1951. The Windermere Laboratory of the Freshwater Biological Association. Hydrobiologia 3 (3): 293-296.

FROST, Winifred E., 1945. The age and growth of eels (Anguilla anguilla) from the Windermere catchment area. Journal of Animal Ecology 14 (1): 26-36.

FROST, Winifred E., 1946. Observations on the food of eels (Anguilla anguilla) from the Windermere catchment area. Journal of Animal Ecology 15 (1): 43-53.

FROST, Winifred E., and Margaret E. BROWN, 1967. The Trout. London.

FRYER, Geoffrey, 1980. Sidnie Milana Manton, 1902-1979. Biogr. Mem. Fellows R. Soc., 26: $327-356$.

HAWORTH, Elizabeth, 2007. Winifred Tutin. The Independent 23 May. p40.

HODGE, Joseph, 2007. Triumph of the Expert: Agrarian Doctrines of Development and the Legacies of British Colonialism. Athens, Ohio.

HUMPHRIES, Carmel, 1936. An investigation of the profundal and sublittoral fauna of Windermere. Journal of Animal Ecology. 5 (1): 29-52.

JENKIN, Penelope, 1936. Reports of the Percy Sladen expedition to some Rift Valley lakes in Kenya in 1929. VII Summary of the ecological results, with special reference to the alkaline lakes. Journal of Natural History 18 (103): 133-179.

JONES, Claire, and Sue HAWKINS, 2015. Guest editorial - women and science. Notes and Records: The Royal Society Journal of the History of Science 69: 5-9.

LANDECKER, Hannah, 2016. Antibiotic resistance and the biology of history. Body and Society 22: 9-52.

LOWE-McCONNELL, Rosemary, 1975. Fish Communities in Tropical Freshwaters: Their Distribution, Ecology and Evolution. London.

LOWE-McCONNELL, Rosemary, 2006. The Tilapia Trail: The Life Story of a Fish Biologist. Ascot.

LUND, John, 1984. Winifred Tutin: a personal note. E. Y. Haworth and J. W. G. Lund, editors. Lake Sediments and Environmental History, pp 1-10. Leicester.

MADSEN-BROOKS, Leslie, 2009. Challenging science as usual: women's participation in American Natural History Museum work, 1870-1950. Journal of Women's History 21: 11-38. 
MARSDEN, Celine, and Anna OMERY, 1992. Women, science, and a women's science. Women's Studies 21: 479-489.

NOAKES, David, 1994. An interview with Ethelwyn Trewavas. Environmental Biology of Fishes 41, 63-65.

OPTIZ, Donald, 2013. 'A triumph of brains over brute': women and science at the Horticultural College, Swanley 1890-1910. Isis 104 (1):30-62.

PEARSALL, William H., and Winifred PENNINGTON, 1947. The ecological history of the English Lake District. Journal of Ecology 34: 137-148.

PEARSALL, William H., and Winifred PENNINGTON, 1973. The Lake District. London.

PENNINGTON, Winifred, 1937. The secondary thickening of Fucus. New Phytologist 36: 267-279.

PENNINGTON, Winifred, 1942. Experiments on the utilisation of nitrogen in fresh waters. Journal of Ecology 30: 326-240.

PENNINGTON, Winifred, 1943. Lake sediments: the bottom deposits of the North Basin of Windermere, with special reference to the diatom succession. New Phytologist 42: 127.

PENNINGTON, Winifred, 1947. Studies on the post-glacial history of British vegetation. VIII Lake sediments: pollen diagrams from the bottom deposits of the North Basin of Windermere. Philosophical Transactions of the Royal Society B 233: 137-175.

PENNINGTON, Winifred, 1949. The ecology of a Lakeland stream. Transactions of the British Bryological Society 1: 166-171.

REID, Gordon McGregor, 2016. Obituary. Rosemary Lowe-McConnell, 1921-2014 (Freshwater Biological Association and British Museum of Natural History). Journal of Fish Biology 88: 443-447.

RICHMOND, Marsha, 1997. 'A lab of one's own'. The Balfour Biological Laboratory for Women at Cambridge University, 1884-1914. Isis 88 (3): 422-455.

SCHIEBINGER, Londa, 1989. The Mind Has No Sex: Women in the Origins of Modern Science. Cambridge, Massachusetts.

SLACK, Nancy, 2010. G. Evelyn Hutchinson and the Invention of Modern Ecology. New Haven, Connecticut.

STIASSNY, Melanie, and Leslie KAUFMAN, 2015. Rosemary Lowe-McConnell, obituary. Environmental Biology of Fishes 98: 1719-1722.

TALLING, Jack F., 2008. The developmental history of inland-water science. Freshwater Reviews 1: 119-141. 
VON OERTZEN, Christine, Maria RENTETZI and Elizabeth WATKINS, 2013. Finding science in surprising places: gender and the geography of scientific knowledge. Centaur 55: $73-80$.

WATTS, Ruth, 2007. Women in Science: A Social and Cultural History. London.

WEST, Candace, and Don ZIMMERMAN, 1987. Doing gender. Gender and Society 1: 125-51.

WORTHINGTON, Edgar Barton, 1943. Freshwater fisheries in the British colonial empire. Nature, 3830: 353-355.

WORTHINGTON, Edgar Barton, 1983. The Ecological Century: A Personal Appraisal. Oxford.

WORTHINGTON, Edgar Barton, 1990. Lord Hailey on the African Survey: some comments. African Affairs 89 (357): 579-583.

WORTHINGTON, Stella, and Edgar Barton WORTHINGTON, 1933. Inland Waters of Africa. The Result of Two Expeditions to the Great Lakes of Kenya and Uganda, with Accounts of their Biology, Native Tribes and Development. London.

\section{ILLUSTRATIONS}

Figure 1. Easter Class, 1941. (Reproduced by permission of the Freshwater Biological Association, Ambleside.)

Figure 2. Dr Penelope Jenkin and the Jenkin Corer, c.1940. (Reproduced by permission of the Freshwater Biological Association, Ambleside.)

Figure 3. Dr Winifred Frost at Bils Tarn, 1941. (Reproduced by permission of the Freshwater Biological Association, Ambleside.) 